\title{
STUDYING THE EFFECT OF SOME PARAMETERS ON QUINOA CROP
}

\author{
Moursy, M. A. M. ${ }^{1}$ ， K. I. Wasfy ${ }^{2}$ and M. H. Rady
}

\section{ABSTRACT}

Agricultural irrigated area depends on the availability of irrigation water. To cope with scarcity of water supplies, deficit irrigation is an important tool to achieve the goal of reducing irrigation water use. Field experiments were carried out to study the effect of forward speed of seed drill (2.1, 3.6, 4.5 and $6.3 \mathrm{~km} / \mathrm{h}$ ), deficit irrigation (zero, 15 and 30\%) and fertilization methods (broadcasting and fertigation) on the amount of water applied, productivity, water and fertilizer use efficiency, net return and net return $/ \mathrm{m}^{3}$ of Quinoa (Chenopodium quinoa $W$.) in sandy soils.

The main results of the study could be summarized as follow:-

-Increasing the forward speed, increased field capacity and therefore, seed scattering was increased, vice versa field efficiency values were decreased.

-Amount of water applied and water consumptive use were (1989 and 1611), (1750 and 1407) and (1527 and 1268) $\mathrm{m}^{3} /$ fed for treatments zero, 15 and $30 \%$ deficit irrigation, respectively. The water saving was 12 and $23.2 \%$ for treatments 15 and 30\% deficit irrigation, respectively as compared with treatment zero deficit irrigation.

-Seed and straw productivity, water and fertilizer use efficiency, net return and net return $/ \mathrm{m}^{3}$ were increased under using fertigation method and forward speed of $3.6 \mathrm{~km} / \mathrm{h}$.

- Net return $/ \mathrm{m}^{3}$ under $15 \%$ deficit irrigation $\left(2.55 \mathrm{LE} / \mathrm{m}^{3}\right)$ was higher than under zero and $30 \%$ deficit irrigation $\left(2.31\right.$ and $\left.2.54 \mathrm{LE} / \mathrm{m}^{3}\right)$ under fertigation method and $3.6 \mathrm{~km} / \mathrm{h}$ forward speed.

- Fertilization by fertigation was more efficiency than broadcasting fertilizers.

\section{INTRODUCTION}

griculture has been and still the backbone of Egyptian national
economy. Therefore, it is vital that any program for economic
development should bear on getting the highest production using

\footnotetext{
${ }^{1}$ Researcher - Water Management Research Institute, National Water Research Center.

${ }^{1}$ Lecturer of Agric. Eng., Fac. of Agric., Zagazig Univ.
} 
the best agricultural techniques with least effort and cost. Modern irrigation methods, mechanization and fertilization techniques are becoming necessary to save water and chemicals fertilization for cultivating new reclamation soil. Quinoa (Chenopodium quinoa W.) which has been an important cultivated food crop in the Peruvian and Bolivian Andes for more than 5000 years and recently it attracted more attention due to its high nutritional values and strong growth potential under the extreme harsh conditions of drought and soil salinity. The nutrient composition is favorable compared with common cereals. Quinoa seeds contain essential amino acids like lysine and acceptable quantities of calcium, phosphorus, and iron. One of the shortcomings overcome by quinoa involves its protein content. Most grains are considered to be inadequate as total protein sources because they lack adequate amounts of the amino acids lysine and isoleucine. By contrast, quinoa has significantly greater amounts of both lysine and isoleucine (especially lysine) and these greater amounts of lysine and isoleucine allow the protein in quinoa to serve as a complete protein source. It is an equally impressive food in terms of its overall phytonutrient benefits. Due to that, Quinoa is newly introduced as a food crop can replenish part of food gap, but; it has more privileges because this crop can be drought, salinity tolerant and could be grown in sandy soil of arid and semiarid regions and with other most harmful abiotic adverse factors that affect crop production (Ogungbenle, 2003 and Shams, 2010).

The main aims which affected on plants were irrigation, sowing methods and fertilizers. Arnaout (1999) reported that the applied fertilizers through the modern irrigation methods (surface drip, subsurface drip and sprinkler) are more efficient than broadcasting fertilizer. He also found that the fertigation through surface and subsurface drip and sprinkler reduced the cost of production unit ( $\mathrm{LE} / \mathrm{Mg}$ ) by $38 \%, 40 \%$ and $33.75 \%$, respectively than broadcasting fertilizer. Erdem et al. (2006) found that increasing drought stress, decreases the grain yield and weight of 1000 grains. Fertigation technique also were indicated to by Abdel-Aziz and El-Bagoury (2008) which proved that fertigation method increased total yield by $11.79-12.62 \%$ under drip and sprinkler irrigation system respectively comparing with the traditional method of fertilization and 
pea yield increased from ( 0.35 to 2.46 ton/fed) and from ( 0.26 to 1.98 ton/fed) with increasing fertigation rate from 30 to $60 \mathrm{~kg} \mathrm{~N} / \mathrm{fed}$ under both drip and sprinkler irrigation systems, respectively. Abou El-Azem (2009) compared among four irrigation levels (60, 80, 100 and 120\% evaporation pan coefficient) under grain sorghum and showed that the irrigation with $80 \%$ gave the best results with regard to yield components and grain yield and the maximum values of water use efficiencies was found when irrigated by $80 \%$. Where, saving water were 46.15, 24.32 and $12.39 \%$ through irrigation using evaporation pan coefficients 60, 80 and $100 \%$ compared to $120 \%$. Ahmad et al. (2009) indicated that with increasing water stress the plant height and plant dry matter decreased under controlled conditions. Fghire et al. (2015) investigate the effect of deficit irrigation (ETc 100\%, 50\%, 33\% and rainfed) and manure fertilization (with $\left(2 \mathrm{~kg} / \mathrm{m}^{2}\right)$ and without manure fertilization) on quinoa crop and found that deficit irrigation of 50\% ETc caused significant reduction in grain yield to the tune of $15.83 \%$ and $15.15 \%$ respectively of the with and without manure compared to $100 \%$ ETc. By increasing deficit irrigation, 33\% ETc and rainfed decreased significantly the grain yield. $50 \%$ ETc gave the highest water use efficiency $\left(1.94 \mathrm{Kg} / \mathrm{m}^{3}\right)$ in comparison to both controls, with and without manure treatments.

Quinoa is a new crop in Egypt and was sowing manually for that the effect of different forward speeds for seed drill was studied to sown quinoa. The fertilizer method effect in fertilizer efficiency, the fertilizer by broadcasting machine leads to losses large amounts of fertilizer for that the fertilizer is evaluated by fertigation.

\section{The objectives of this study are:}

1- To evaluate some different parameters of seed drill forward speed, deficit irrigation and fertilization methods that affecting on the quinoa crop production.

2- To determine the highest water and fertilizer use efficiency and net return of different seed drill forwards speed and deficit irrigation under fertilization method.

\section{MATERIALS AND METHODS}

Field experiments were carried out on sandy soil through agricultural season of 2013/2014 at private farm in El-Khattara, Sharkia Governorate, 
Egypt. El-Khattara is situated at $30^{\circ} 38^{\prime} 24^{\prime \prime} \mathrm{N}$ latitude, $31^{\circ} 50^{\prime} 54^{\prime \prime} \mathrm{E}$ longitude. Total area of the farm was 10 feddans.

\section{Materials}

1.1. Soil analysis: Soil samples from each plot were taken from $0-20 \mathrm{~cm}$ and $20-40 \mathrm{~cm}$ depth before planting quinoa crop and then, the mechanical properties were analyzed according to standard methods of Peterson and Calvin (1965) and APHA (1989) as shown in Table (1).

Table (1): Soil mechanical analysis

\begin{tabular}{|c|c|c|c|c|c|c|c|c|}
\hline \multirow{2}{*}{$\begin{array}{c}\text { Soil } \\
\text { layer, } \\
\text { cm }\end{array}$} & \multicolumn{3}{|c|}{$\begin{array}{c}\text { Particle size } \\
\text { distribution, \% }\end{array}$} & \multirow{2}{*}{$\begin{array}{l}\text { Texture } \\
\text { class }\end{array}$} & \multirow{2}{*}{$\begin{array}{l}\text { Bulk density, } \\
\mathrm{g} / \mathrm{cm}^{3}\end{array}$} & \multicolumn{3}{|c|}{$\begin{array}{c}\text { Moisture content, } \\
\%\end{array}$} \\
\hline & Sand & Silt & Clay & & & F. C. & W.P. & A.W. \\
\hline $0-20$ & & & 2.3 & & & 11 & 5.0 & 6.0 \\
\hline $20-40$ & 89.1 & 9 & 1.9 & salu & 1.24 & 10.7 & 5.1 & 5.6 \\
\hline
\end{tabular}

1.2. Crop: Quinoa crop was used under this study in order to select the optimum conditions for its planting, fertilizing and water requirements under Egyptian conditions. Quinoa was sown at the rate of $4 \mathrm{~kg} / \mathrm{fed}$ and planted at dates of $5^{\text {th }}$ Nov. and harvesting date $10^{\text {th }}$ May. The physical and mechanical properties of quinoa seeds were determined as shown in Table (2).

Table (2): Physical and mechanical properties of Quinoa seeds

\begin{tabular}{|l|r|l|c|}
\hline \multicolumn{2}{|c|}{ Physical properties } & \multicolumn{2}{c|}{ Mechanical properties } \\
\hline Length, mm & 1.91 & \multirow{2}{*}{ Repose angle, degree } & 33 \\
\cline { 1 - 2 } Width, $\mathrm{mm}$ & 1.86 & & 27 \\
\hline Thickness, $\mathrm{mm}$ & 1.26 & Friction angle, degree & 27 \\
\cline { 1 - 2 } Mass of 1000 seeds, g & 30 & \multirow{2}{*}{ Coefficient of friction } & 0.51 \\
\hline Bulk density, g/cm & 0.67 & & \\
\hline
\end{tabular}

1.3. Water analysis: water samples were taken from water pump and the chemical analysis was determined as shown in Table (3).

Table (3): Chemical analysis of water.

\begin{tabular}{|c|c|c|c|c|c|c|c|c|c|}
\hline \multirow{2}{*}{$\mathbf{p H}$} & \multirow{2}{*}{$\begin{array}{c}\text { EC } \\
\end{array}$} & \multicolumn{4}{|c|}{ Soluble Cations (meq) } & \multicolumn{4}{|c|}{ Soluble Anions (meq/L) } \\
\cline { 3 - 10 } & $\mathbf{~ K}^{+}$ & $\mathbf{N a}^{+}$ & $\mathbf{M g}^{++}$ & $\mathbf{C a}^{++}$ & $\mathbf{S o}_{4}^{-}$ & $\mathbf{C l}^{-}$ & $\mathbf{H C O}_{3}^{-}$ & $\mathbf{C O}_{3}^{-}$ \\
\hline 7.5 & 1.76 & 10.2 & 6.4 & 4.6 & 0.8 & 9.7 & 6.4 & - & 6.3 \\
\hline
\end{tabular}

1.4. Fertilizer: The fertilizer of calcium super phosphate $\left(15 \% \mathrm{P}_{2} \mathrm{O}_{5}\right)$ was applied during soil preparation at the rate of $30 \mathrm{~kg} / \mathrm{fed}$. Nitrogen in 
the form of ammonium sulfate $(20.5 \%)$ was added at the rate of 150 $\mathrm{kg} /$ fed at four equal doses under broadcasting method but under fertigation method at 8 doses, according to Shams (2012).

\subsection{Machinery and equipment:}

1.5.1. Tractor Kubota V 1702 - DI - A: Tractor L 2850 (4WD), made in Japan, engine power $25.4 \mathrm{~kW}$ (34 hp), direct injection, water cooled, 4 cycles diesel, 4 cylinders, engine rated speed $2600 \mathrm{rpm}$ and mass 1230 $\mathrm{kg}$.

1.5.2. Seed drill: Mounted seed drill, model Colorado, made in Italy, 21 tubes, spacing between tubes $10 \mathrm{~cm}$ and mass $350 \mathrm{~kg}$.

1.5.3. Broadcasting machine: Mounted broadcaster, model Rond INI SR 250, made in Italy, 6 blades and $250 \mathrm{~kg}$ capacity.

1.6. Irrigation system: The sprinkler irrigation system was used under study. Control head consist of centrifugal pump, pressure regulator, pressure gauges, flow meter and filters. The main, sub-main, secondary and lateral lines were made from PVC pipes that having diameters of 125, 110, 90 and $63 \mathrm{~mm}$, respectively. The distance between lateral lines and between the sprinklers as shown in Fig. (1) was $12 \mathrm{~m}$, sprinkler riser 0.75 inch diameter and $75 \mathrm{~cm}$ height above soil. Rotating sprinklers 0.75 inch out diameter, $1.25 \mathrm{~m}^{3} / \mathrm{h}$ discharge 2.2 bar operating pressure.

\section{Methods}

The experimental area was about 1.65 fed cultivated with quinoa. They divided into two main plots for broadcasting machine and fertigation method, the main plots have dimensions of 12 x $96 \mathrm{~m}$. The experiments were carried out in a split-split plot design Fig. (1)

\subsection{Experimental condition}

Field experiments were conducted under the following variables:-

- The main treatment (two fertilization methods (broadcasting machine and fertigation).

- The sub main (four seed drill forward speeds (2.1, 3.6, 4.5 and 6.3 $\mathrm{km} / \mathrm{h})$ ).

- The sub sub main (three deficit irrigation (zero, 15 and 30\%)).

Planting quinoa was carried out by using seed drill at an average depth of $2.5 \mathrm{~cm}$ under previous mentioned forward speeds. The average forward speed of broadcasting machine was $6 \mathrm{~km} / \mathrm{h}$. 


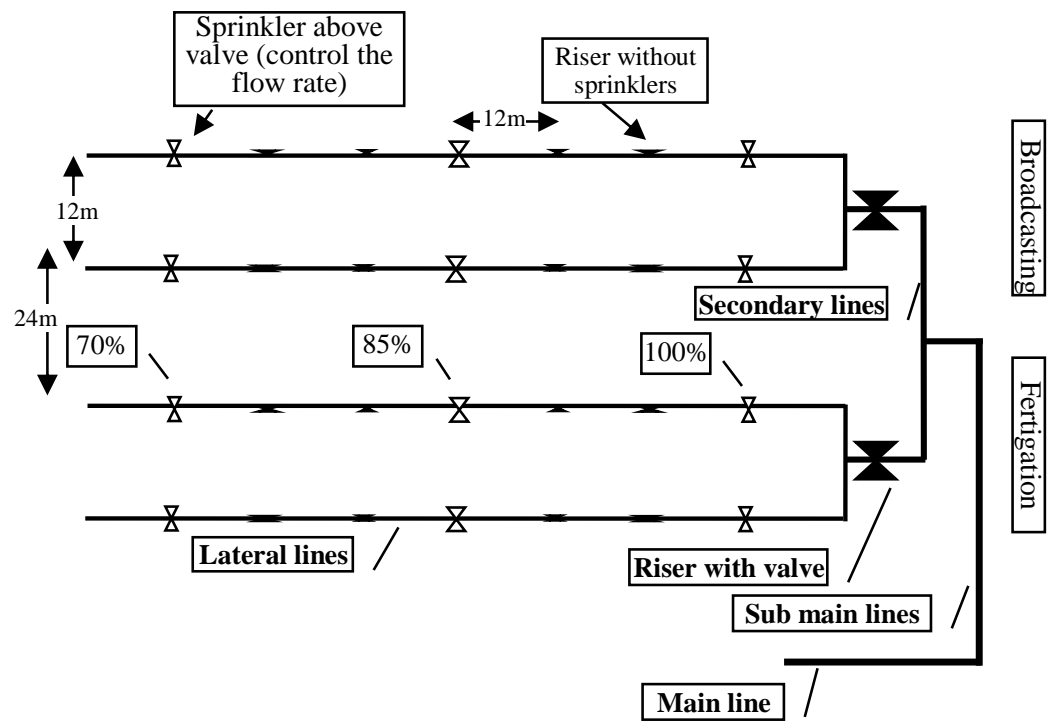

Fig. (1), Schematic of the used sprinkler irrigation system

\subsection{Measurement and determinations}

\subsubsection{Seed scattering}

Seed scattering is very important parameter to determine the performance of planting machines. It was determined according to the following formula (Snedecor and Cochran, 1967) as,

Where:

$$
C . V .=\frac{\sigma n-1}{\bar{x}} \times 100 \quad \sigma n-1=\sqrt{\frac{\sum(x-\bar{x})^{2}}{n-1}}
$$

C.V.: Coefficient of variation between row from average distance, $\%$
$\sigma n-1:$ Standard deviation
$x$ : The average distance
$\mathrm{x}$ : Distance between rows
$\mathrm{n}$ : Number of readings

\section{Field capacity and efficiency}

The theoretical field capacity is the rate of the field coverage that will be obtained if the machine is performed its function $100 \%$ of the time at the rated forward speed and always cover $100 \%$ of its rated width (Kepner et al. 1978). Thus, it was calculated as:

$$
\mathrm{T}_{\mathrm{f} . \mathrm{c} .}=\left(\mathrm{W}_{\mathrm{m}} \times \mathrm{F}_{\mathrm{s}}\right) / 4.2
$$

Where: $T_{\text {f.c: }}$ Theoretical field capacity, fed/h

$$
\mathrm{W}_{\mathrm{m}} \text { : Width of the machine, } \mathrm{m} \quad \mathrm{F}_{\mathrm{s}} \text { Forward speed, } \mathrm{km} / \mathrm{h}
$$

However, actual field capacity $\left(\mathrm{A}_{\text {f.c. }}\right)$ is based upon the total effective operating time (Kepner et al. 1978). Thus, it was calculated as: 


$$
\mathrm{A}_{\mathrm{f} . \mathrm{c}}=1 / \mathrm{T}_{\mathrm{t}}
$$

Where: $\mathrm{T}_{\mathrm{t}}$ : Actual total time in hours required per feddan, $\mathrm{h} / \mathrm{fed}$ While, the field efficiency $\left(\eta_{\mathrm{f}}\right)$ was calculated by using the following formula:

$$
\eta_{f}=\left(A_{\text {f.c. }} / T_{\text {f.c. }}\right) \times 100
$$

\section{Power and energy requirements.}

The required power $(E P)$ was calculated using the following formula according to (Embaby, 1985).

Where:

$$
\mathrm{EP}=\left(\mathrm{F}_{\mathrm{c}} \times \frac{1}{3600}\right) \times \mathrm{p}_{\mathrm{f}} \times \text { L. C. V. } \times 427 \times \mu_{\mathrm{th}} \times \mu_{\mathrm{m}} \times \frac{1}{75} \times \frac{1}{1.36}, \mathrm{~kW}
$$

$\mathrm{F}_{\mathrm{c}}=$ Fuel consumption, $l / h$

$\rho_{\mathrm{f}}=$ Density of diesel fuel $(0.85 \mathrm{~kg} / \mathrm{l})$

L.C.V. $=$ Lower calorific value of diesel fuel $(10000 \mathrm{kcal} / \mathrm{kg})$

$427=$ Thermo-mechanical equivalent, $\mathrm{kg} . \mathrm{m} / \mathrm{kcal}$

$\eta_{\mathrm{th}}=$ Thermal efficiency of diesel engine, $(40 \%)$

$\eta_{\mathrm{m}}=$ Mechanical efficiency of diesel engine, $(80 \%)$.

The Energy Requirements (ER) was estimated using the following equation:-

$$
\mathrm{ER}=\frac{\text { Required power }(\mathrm{kW})}{\text { A fielctual field capicity (fed./h) }}, \mathrm{kW} . \mathrm{h} / \mathrm{fed}
$$

\subsubsection{Amount of water applied}

The irrigation requirements was calculated according to the equation given by Israelsen and Hansen (1962) as follows:

$$
\mathrm{D}_{\text {aiw }}=\frac{\text { F.C. }-\theta_{1}}{100} \mathrm{XB}_{\mathrm{d}} \mathrm{Xd}
$$

Where:
$\mathrm{D}_{\text {aiw }}$ : Depth of irrigation water applied
F. C.: Soil moisture content at field capacity
$(\mathrm{mm})$
$\Theta_{1}$ : Soil moisture content before irrigation
$\mathrm{B}_{\mathrm{d}}$ : Bulk density
d : Soil depth $\left(\mathrm{g} / \mathrm{cm}^{3}\right)$ $(\mathrm{mm})$

\subsubsection{Water Consumptive Use}

The actual water consumptive use was calculated using the following equation described by Israelsen and Hansen (1962) as the follow:

$$
\mathrm{W}_{\mathrm{cu}}=\frac{\theta_{2}-\theta_{1}}{100} \mathrm{XB}_{\mathrm{d}} \mathrm{Xd}
$$




\section{Where:}
$\mathrm{W}_{\mathrm{cu}}$ : Water consumptive use
$(\mathrm{mm})$
$\Theta_{2}$ : Soil moisture content after irrigation

2.2.4. Yield components at harvest, samples of plants were taken from each treatment to estimate the following:

- Plant height $(\mathrm{cm})$.

- Seed yield (kg/fed.).

- Straw yield (kg/fed.).

\subsubsection{Water use efficiency (WUE):}

It was determined according to (Pene and Edi, 1996) using the following equation:

\subsubsection{Fertilizer use efficiency (FUE):}

$$
\text { WUE }=\frac{\text { Yield }(\mathrm{kg} / \mathrm{fed} .)}{\text { Amount of water applied }\left(\mathrm{m}^{3} / \mathrm{fed}\right)}, \mathrm{kg} / \mathrm{m}^{3}
$$

It was determined using the following equation as sited from Abdel-Aziz and El-Bagoury (2008):

$$
\mathrm{FUE}=\frac{\text { Yield }(\mathrm{kg} / \mathrm{fed})}{\text { Total applied nitrogen }(\mathrm{kg} / \mathrm{fed})}, \mathrm{kg} \text { yield } / \mathrm{kg} \text { nitrogen }
$$

\subsubsection{Economic analysis}

- Total return (LE/fed.) was calculated with the following equation:

Total return $=$ price $(\mathrm{LE} / \mathrm{kg}) \times$ productivity $(\mathrm{kg} / \mathrm{fed})$

- Total costs (LE/fed.) was calculated with the following equation:

Total cost $=$ fixed cost + variable cost

- Net return (LE/fed.) was calculated with the following equation:

Net return $=$ Total return - Total costs

- Net return $/ \mathrm{m}^{3}\left(\mathrm{LE} / \mathrm{m}^{3}\right)$ was calculated by using the following formula:

$$
\text { Net return } / \mathrm{m}^{3}=\frac{\text { Net return }(\mathrm{LE} / \mathrm{fed} \text {. })}{\text { Amount of water applied }\left(\mathrm{m}^{3} / \mathrm{fed}\right)}, \mathrm{LE} / \mathrm{m}^{3}
$$

\subsubsection{Statistical analysis:}

Data were subjected to statistical analysis according to Snedecor and Cochran (1990). This statistical was done by SPSS program.

\section{RESULTS AND DISCUSSION}

The obtained results will be discussed under the following heads:- 


\section{Seed scattering}

Results of the effect of seed drill forward speed on quinoa seed scattering as shown in Fig. (2) clarified that increasing forward speed from 2.1 to $6.3 \mathrm{~km} / \mathrm{h}$, increased seed scattering from 4.02 to $7.05 \%$. Increasing the forward speed, increased the machine vibration, more slip occurred and therefore, seed scattering was increased.

\section{Field capacity and field efficiency}

The effect of forward speed on field capacity and field efficiency in Fig. (3) showed that increasing forward speed from 2.1 to $6.3 \mathrm{~km} / \mathrm{h}$, increased field capacity from 0.89 to $1.83 \mathrm{fed} / \mathrm{h}$. While, field efficiency values were decreased by increasing the forward speed. Increasing forward speed from 2.1 to $6.3 \mathrm{~km} / \mathrm{h}$, decreased field efficiency values from 84.76 to $58.10 \%$. The major reason for this reduction in field efficiency by increasing forward speed was due to the less theoretical time consumed in comparison with the other items of time losses.

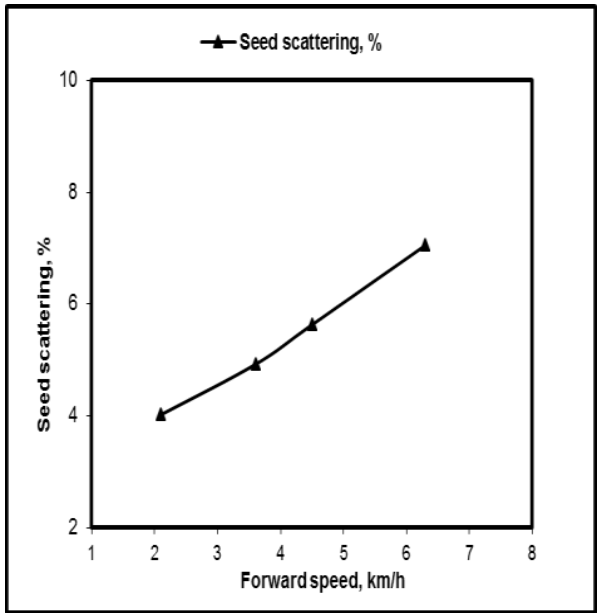

Fig. (2): Effect of seed drill forward speed on seed scattering.

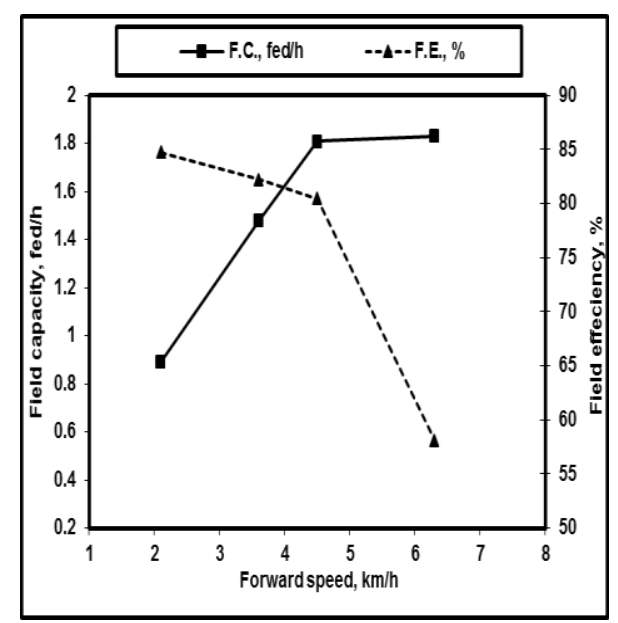

Fig. (3): Effect of seed drill forward speed on field capacity and field efficiency.

Amount of water applied, water consumptive use and water saving

The presented data indicated clearly that the amount of water applied and water consumptive use varied greatly according to the variation in the treatments. It can be noticed that amount of water applied and water consumptive use were (1989 and 1611), (1750 and 1407) and (1527 and 1268) $\mathrm{m}^{3} / \mathrm{fed}$, for treatments zero, 15 and $30 \%$ deficit irrigation, 
respectively. It can be concluded that amount of water applied was lower with treatment of $30 \%$ deficit irrigation than these applied with other treatments while, the highest volume of applied water was found to be under the zero deficit irrigation treatment, where full irrigation $100 \%$ of amount of water applied was practiced during the whole cropping period. On the other hand, 30\% deficit irrigation where lower irrigation was the one with the lowest irrigation volume corresponding to only $23.2 \%$ of that of the zero deficit irrigation.

The water saving was 12 and $23.2 \%$ for treatments 15 and $30 \%$ deficit irrigation, respectively compared with treatment of zero deficit irrigation.

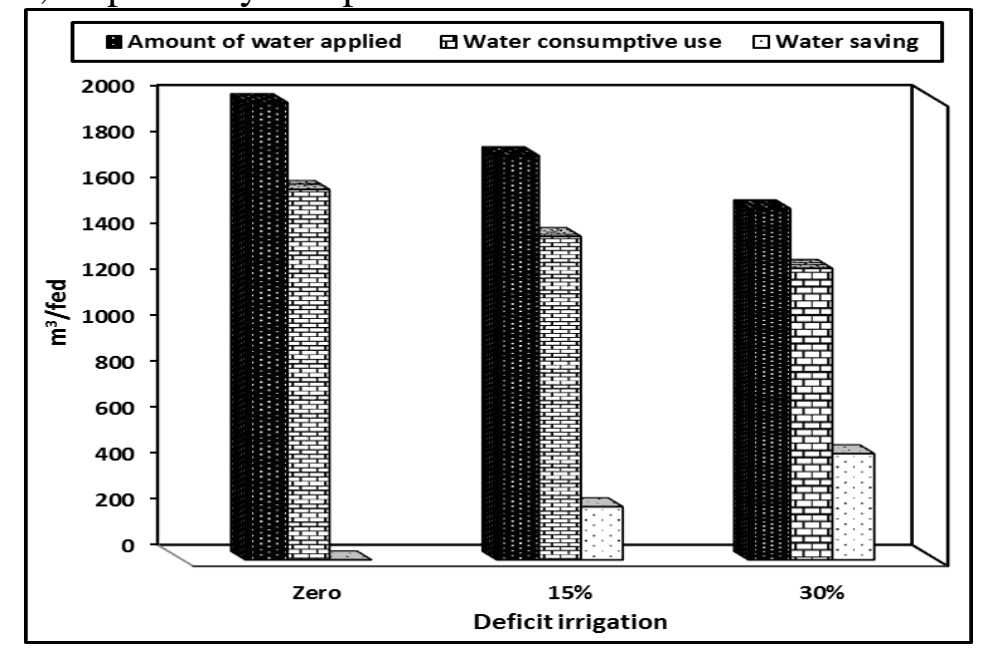

Fig. (4): Amount of water applied, water consumptive use and water saving under investigated irrigation treatments.

\section{Plant height}

The statistical analysis of the data showed significant effect for plant height under study as influenced by fertilizer method. The values are presented in Table 4. Data clarified that by using fertigation method the plant height was increased compared with broadcasting. Fertigation method increased the plant height by $7.9 \%$ compared with broadcasting. Regarding to seed drill forward speed, the results reveal that there was no significant in plant height. Increasing forward speed from 2.1 to 6.3 $\mathrm{km} / \mathrm{h}$, decreased plant height under different treatments. By increasing forward speed from 2.1 to $6.3 \mathrm{~km} / \mathrm{h}$ decreased the plant height from 
141.37 to $134.33 \mathrm{~cm}$ and from 153.67 to $143.67 \mathrm{~cm}$ under broadcasting and fertigation methods, respectively. The increase in plant height at lower forward speed was attributed to the increase in plant population because under high plant population, the competition among adjacent plants pushed them in the vertical direction to obtain enough light.

With regard to the effect of deficit irrigation, statistical analysis revealed that deficit irrigation had a significant effect on plant height. Decreasing deficit irrigation from 30 to zero\% the plant height increased from 119.03 to $151 \mathrm{~cm}$ and from 132.5 to $163.96 \mathrm{~cm}$ under broadcasting and fertigation methods.

Interaction between fertilizer method, forward speed and deficit irrigation was insignificant.

Table 4: The plant height $(\mathrm{cm})$ of quinoa under the effect of deficit irrigation, forward speed and fertilizer methods.

\begin{tabular}{|c|c|c|c|c|c|}
\hline \multirow{2}{*}{$\begin{array}{l}\text { Fertilizer } \\
\text { methods }\end{array}$} & \multirow{2}{*}{$\begin{array}{c}\text { Forward } \\
\text { speed }\end{array}$} & \multicolumn{3}{|c|}{ Deficit irrigation } & \multirow[t]{2}{*}{ Mean } \\
\hline & & Zero & $15 \%$ & $30 \%$ & \\
\hline \multirow{4}{*}{ Broadcasting } & 2.1 & 155 & 147 & 122 & 141.37 \\
\hline & 3.6 & 152 & 145 & 121 & 139.33 \\
\hline & 4.5 & 150 & 144 & 118 & 137.33 \\
\hline & 6.3 & 147 & 141 & 115 & 134.33 \\
\hline \multicolumn{2}{|c|}{ Mean } & 151 & 144.25 & 119.03 & 138.09 \\
\hline \multirow{4}{*}{ Fertigation } & 2.1 & 167 & 156 & 138 & 153.67 \\
\hline & 3.6 & 166 & 152 & 135 & 150.94 \\
\hline & 4.5 & 162 & 150 & 132 & 148 \\
\hline & 6.3 & 161 & 145 & 125 & 143.67 \\
\hline \multicolumn{2}{|c|}{ Mean } & 163.96 & 150.75 & 132.5 & 149.07 \\
\hline
\end{tabular}

LSD at $5 \%$

Fertilizer methods (F) S

Forward speed (S) N.S

Deficit irrigation (D) $\quad \mathrm{S}$

F*S N.S

$F^{*} \mathbf{D} \quad$ N.S

S*D N.S

$\mathbf{F} * \mathbf{S} * \mathbf{D} \quad$ N.S

\section{Seed and Straw productivity}

Data in Table 5 showed that deficit irrigation and fertilization methods significantly affect in seed productivity while forward speed had insignificant effect. 
Relating to fertilizer method, data indicated that seed productivity increased significantly by using fertigation method compared with broadcasting. The highest value of seed productivity was $664.93 \mathrm{~kg} / \mathrm{fed}$ under fertigation method. The increase in productivity may be due to the fertigation as attractive concept, as it permits application of nutrients directly at the site of a high concentration of active roots and as needed by the quinoa plants, while applying the fertilizers using broadcasting method causes non-uniformity distribution of fertilizer through the soil profile and consequently, decreasing fertilizer utilization efficiency and crops productivity (El-Gindy, 1988).

With regard to the effect of deficit irrigation, it is obvious that the decreasing of irrigation by 15 and $30 \%$ decreased the seed productivity by (3.5 and $17.3 \%)$ and (3.9 and 15.9\%) under broadcasting and fertigation method, respectively than treatment with no decreasing of irrigation (zero).

As to effect of seed drill forward speed, the seed productivity was increased by increasing forward speed up to $3.6 \mathrm{~km} / \mathrm{h}$ and then, decreased. Seed productivity was increased from 595 to $627 \mathrm{~kg} / \mathrm{fed}$ and from 664 to $709.67 \mathrm{~kg} / \mathrm{fed}$ with increasing forward speed from 2.1 to 3.6 $\mathrm{km} / \mathrm{h}$, while it decreased from 627 to $568.31 \mathrm{~kg} / \mathrm{fed}$ and from 709.67 to $639.18 \mathrm{~kg} / \mathrm{fed}$ by increasing forward speed from 3.6 to $6.3 \mathrm{~km} / \mathrm{h}$ under broadcasting and fertigation methods, respectively.

With regard to the effect of different treatments on straw productivity, statistical analysis revealed that different forward speed, deficit irrigation and fertilization methods had a significant effect on straw productivity. Table 5 showed that fertigation methods produced higher straw productivity compared to broadcasting methods. With increasing the deficit irrigation the straw productivity decreased. By increasing forward speed from 2.1 to $3.6 \mathrm{~km} / \mathrm{h}$ the straw productivity was increased, while increasing forward speed to 4.5 and $6.3 \mathrm{~km} / \mathrm{h}$ the straw productivity decreased.

Interaction between fertilizer method, forward speed and deficit irrigation was insignificant. 
Table 5: seed and straw productivity of quinoa under the effect of deficit irrigation, forward speed and fertilizer methods.

\begin{tabular}{|c|c|c|c|c|c|c|c|c|c|}
\hline \multirow{3}{*}{$\begin{array}{l}\text { Fertilizer } \\
\text { methods }\end{array}$} & \multirow{3}{*}{$\begin{array}{c}\text { Forward } \\
\text { speed } \\
\end{array}$} & \multicolumn{4}{|c|}{ Seed } & \multicolumn{4}{|c|}{ Straw } \\
\hline & & \multicolumn{3}{|c|}{ Deficit irrigation } & \multirow[t]{2}{*}{ Mean } & \multicolumn{3}{|c|}{ Deficit irrigation } & \multirow[t]{2}{*}{ Mean } \\
\hline & & Zero & $15 \%$ & $30 \%$ & & Zero & $15 \%$ & $30 \%$ & \\
\hline \multirow{4}{*}{ Broadcasting } & 2.1 & 633 & 614 & 538 & 595 & 1077 & 1002 & 829 & 969.33 \\
\hline & 3.6 & 667 & 640 & 574 & 627 & 1156 & 1087 & 925 & 1056 \\
\hline & 4.5 & 614.01 & 599.26 & 525.63 & 579.63 & 1055.5 & 984.97 & 816.57 & 952.33 \\
\hline & 6.3 & 608.3 & 583.08 & 513.54 & 568.31 & 1029.3 & 974.13 & 804.32 & 935.92 \\
\hline \multicolumn{2}{|c|}{ Mean } & 630.58 & 609.09 & 537.79 & 592.49 & 1079.4 & 1012 & 843.72 & 978.4 \\
\hline \multirow{4}{*}{ Fertigation } & 2.1 & 701 & 681 & 610 & 664 & 1198 & 1102 & 982 & 1094 \\
\hline & 3.6 & 755 & 725 & 649 & 709.67 & 1310 & 1231 & 1074 & 1205 \\
\hline & 4.5 & 679.97 & 664.66 & 595.97 & 646.87 & 1174 & 1083.3 & 967.27 & 1074.9 \\
\hline & 6.3 & 688.56 & 646.71 & 582.26 & 639.18 & 1166.4 & 1071.4 & 952.76 & 1063.5 \\
\hline \multicolumn{2}{|c|}{ Mean } & 706.13 & 679.34 & 609.31 & 664.93 & 1212.1 & 1121.9 & 994.01 & 1109.3 \\
\hline
\end{tabular}

LSD at $5 \%$

$\begin{array}{lll}\text { Fertilizer methods (F) } & \mathbf{S} & \mathbf{S} \\ \text { Forward speed (S) } & \text { N.S } & \text { S } \\ \text { Deficit irrigation (D) } & \mathbf{S} & \mathbf{S} \\ \mathbf{F} * \mathbf{S} & \text { N.S } & \text { N.S } \\ \mathbf{F} * \mathbf{D} & \text { N.S } & \text { N.S } \\ \mathbf{S} * \mathbf{D} & \text { N.S } & \text { N.S } \\ \mathbf{F} * \mathbf{S} * \mathbf{D} & \text { N.S } & \text { N.S }\end{array}$

\section{Water use efficiency}

The water use efficiency of seed and straw as affected by fertilizer method, seed drill forward speed and deficit irrigation and combined of them are presented in Table 6.

The results indicated that water use efficiency of seed was significant affected by fertilizer method and deficit irrigation, while insignificant affected by forward speed.

By using fertigation method the water use efficiency increased compared with broadcasting method. Fertigation method increased seed water use efficiency by $11.8 \%$ compared with broadcasting method.

As to effect of deficit irrigation, illustrated data in Table 6 indicated that the seed water use efficiency increased with increasing deficit irrigation. Deficit irrigation 30\% increased seed water use efficiency by 2.5 and $11.11 \%$ compared with 15 and zero deficit irrigation under fertigation method. 
Results showed that the average seed water use efficiency under forward speed of $3.6 \mathrm{~km} / \mathrm{h}\left(0.41 \mathrm{~kg} / \mathrm{m}^{3}\right)$ was higher than that under $2.1,4.5$ and 6.3 $\mathrm{km} / \mathrm{h}\left(0.38,0.37\right.$ and $\left.0.37 \mathrm{~kg} / \mathrm{m}^{3}\right)$ by $7.9,10.8$ and $10.8 \%$ under fertigation method.

The results indicated that water use efficiency of straw was significant affected by fertilizer method, while insignificant affected by forward speed and deficit irrigation.

Straw water use efficiency under fertigation method was higher than that under broadcasting method. Also, the straw water use efficiency increased with increasing deficit irrigation under different forward speed.

Interaction between fertilizer method, forward speed and deficit irrigation was insignificant.

Table 6: seed and straw water use efficiency of quinoa under the effect of deficit irrigation, forward speed and fertilizer methods.

\begin{tabular}{|c|c|c|c|c|c|c|c|c|c|}
\hline \multirow{3}{*}{$\begin{array}{c}\text { Fertilizer } \\
\text { methods }\end{array}$} & \multirow{3}{*}{$\begin{array}{c}\text { Forward } \\
\text { speed }\end{array}$} & \multicolumn{4}{|c|}{ Seed } & \multicolumn{4}{|c|}{ Straw } \\
\hline & & \multicolumn{3}{|c|}{ Deficit irrigation } & \multirow[t]{2}{*}{ Mean } & \multicolumn{3}{|c|}{ Deficit irrigation } & \multirow[t]{2}{*}{ Mean } \\
\hline & & Zero & $15 \%$ & $30 \%$ & & Zero & $15 \%$ & $30 \%$ & \\
\hline \multirow{4}{*}{ Broadcasting } & 2.1 & 0.32 & 0.35 & 0.35 & 0.34 & 0.54 & 0.57 & 0.54 & 0.55 \\
\hline & 3.6 & 0.34 & 0.36 & 0.38 & 0.36 & 0.58 & 0.62 & 0.61 & 0.60 \\
\hline & 4.5 & 0.31 & 0.34 & 0.34 & 0.33 & 0.53 & 0.56 & 0.53 & 0.54 \\
\hline & 6.3 & 0.31 & 0.33 & 0.34 & 0.32 & 0.52 & 0.55 & 0.53 & 0.53 \\
\hline \multicolumn{2}{|c|}{ Mean } & 0.32 & 0.35 & 0.35 & 0.34 & 0.54 & 0.58 & 0.55 & 0.56 \\
\hline \multirow{4}{*}{ Fertigation } & 2.1 & 0.35 & 0.39 & 0.40 & 0.38 & 0.60 & 0.63 & 0.64 & 0.62 \\
\hline & 3.6 & 0.38 & 0.41 & 0.42 & 0.41 & 0.66 & 0.70 & 0.70 & 0.69 \\
\hline & 4.5 & 0.34 & 0.38 & 0.39 & 0.37 & 0.59 & 0.62 & 0.63 & 0.61 \\
\hline & 6.3 & 0.35 & 0.37 & 0.38 & 0.37 & 0.59 & 0.61 & 0.62 & 0.61 \\
\hline \multicolumn{2}{|c|}{ Mean } & 0.36 & 0.39 & 0.40 & 0.38 & 0.61 & 0.64 & 0.65 & 0.63 \\
\hline
\end{tabular}

LSD at $5 \%$

$\begin{array}{lll}\text { Fertilizer methods }(\text { F) } & \text { S } & \text { S } \\ \text { Forward speed (S) } & \text { N.S } & \text { N.S } \\ \text { Deficit irrigation (D) } & \text { S } & \text { N.S } \\ \text { F*S } & \text { N.S } & \text { N.S } \\ \text { F*D } & \text { N.S } & \text { N.S } \\ \text { S*D } & \text { N.S } & \text { N.S } \\ \text { F*S*D } & \text { N.S } & \text { N.S }\end{array}$

\section{Fertilizer use efficiency}

From statistical analysis data indicated that forward speed, deficit irrigation and fertilizer methods had a significant influence on fertilizer 
use efficiency. Results showed that the highest value of seed and straw fertilizer use efficiency were 5.03 and $8.73 \mathrm{~kg} / \mathrm{kg}-\mathrm{N}$ under conditions of using fertigation method, $3.6 \mathrm{~km} / \mathrm{h}$ forward speed and zero deficit irrigation.

Data as illustrated in Table 7 indicated that fertilizer use efficiency under fertigation method was higher than that under the broadcasting method. This may be due to the fertilizer elements in solution become available to the plant root faster than when placed dry in the soil by broadcaster.

Table 7: seed and straw fertilizer use efficiency of quinoa under the effect of deficit irrigation, forward speed under fertilizer methods.

\begin{tabular}{|c|c|c|c|c|c|c|c|c|c|}
\hline \multirow{3}{*}{$\begin{array}{l}\text { Fertilizer } \\
\text { methods }\end{array}$} & \multirow{3}{*}{$\begin{array}{c}\text { Forward } \\
\text { speed }\end{array}$} & \multicolumn{4}{|c|}{ Seed } & \multicolumn{4}{|c|}{ Straw } \\
\hline & & \multicolumn{3}{|c|}{ Deficit irrigation } & \multirow[t]{2}{*}{ Mean } & \multicolumn{3}{|c|}{ Deficit irrigation } & \multirow[t]{2}{*}{ Mean } \\
\hline & & Zero & $15 \%$ & $30 \%$ & & Zero & $15 \%$ & $30 \%$ & \\
\hline \multirow{4}{*}{ Broadcasting } & 2.1 & 4.22 & 4.09 & 3.59 & 3.97 & 7.18 & 6.68 & 5.53 & 6.46 \\
\hline & 3.6 & 4.45 & 4.27 & 3.83 & 4.18 & 7.71 & 7.25 & 6.17 & 7.04 \\
\hline & 4.5 & 4.09 & 4.00 & 3.50 & 3.86 & 7.04 & 6.57 & 5.44 & 6.35 \\
\hline & 6.3 & 4.06 & 3.89 & 3.42 & 3.79 & 6.86 & 6.49 & 5.36 & 6.24 \\
\hline \multicolumn{2}{|c|}{ Mean } & 4.20 & 4.06 & 3.59 & 3.95 & 7.20 & 6.75 & 5.62 & 6.52 \\
\hline \multirow{4}{*}{ Fertigation } & 2.1 & 4.67 & 4.54 & 4.07 & 4.43 & 7.99 & 7.35 & 6.55 & 7.29 \\
\hline & 3.6 & 5.03 & 4.83 & 4.33 & 4.73 & 8.73 & 8.21 & 7.16 & 8.03 \\
\hline & 4.5 & 4.53 & 4.43 & 3.97 & 4.31 & 7.83 & 7.22 & 6.45 & 7.17 \\
\hline & 6.3 & 4.59 & 4.31 & 3.88 & 4.26 & 7.78 & 7.14 & 6.35 & 7.09 \\
\hline \multicolumn{2}{|c|}{ Mean } & 4.71 & 4.53 & 4.06 & 4.43 & 8.08 & 7.48 & 6.63 & 7.40 \\
\hline
\end{tabular}

LSD at $5 \%$

$\begin{array}{lll}\text { Fertilizer methods }(\mathbf{F}) & \mathbf{S} & \mathbf{S} \\ \text { Forward speed (S) } & \mathbf{S} & \mathbf{S} \\ \text { Deficit irrigation }(\mathbf{D}) & \text { N.S } & \mathbf{S} \\ \mathbf{F} * \mathbf{S} & \text { N.S } & \text { N.S } \\ \mathbf{F} * \mathbf{D} & \text { N.S } & \text { N.S } \\ \mathbf{S} * \mathbf{D} & \text { N.S } & \text { N.S } \\ \mathbf{F} * \mathbf{S} * \mathbf{D} & \text { N.S } & \text { N.S }\end{array}$

By decreasing deficit irrigation, fertilizer use efficiency increased.

Regarding the effect of different forward speed on fertilizer use efficiency. It is found that the fertilizer use efficiency was increased by increasing forward speed from 2.1 to $3.6 \mathrm{~km} / \mathrm{h}$ and then, decreased. 
As to effect of fertilizer method, the seed and straw fertilizer use efficiency values were 4.45 and $7.71 \mathrm{~kg} / \mathrm{kg}-\mathrm{N}$ under zero deficit irrigation, forward speed of $3.6 \mathrm{~km} / \mathrm{h}$ under broadcasting machine.

Interaction between fertilizer method, forward speed and deficit irrigation was insignificant.

\section{Economic evaluation}

Economic evaluation asked for estimating different cost items achieve related to different treatments as well as total returns. According, net returns and net returns $/ \mathrm{m}^{3}$ were estimated. Table (8) shows that the lowest total cost of quinoa production was $2333 \mathrm{LE} / \mathrm{fed}$ under $30 \%$ deficit irrigation at forward speed of $3.6 \mathrm{~km} / \mathrm{h}$ and fertigation method, while the highest total cost of quinoa production was $2714 \mathrm{LE} / \mathrm{fed}$ under zero deficit irrigation at forward speed of $2.1 \mathrm{~km} / \mathrm{h}$ and broadcasting method.

Table (8): Effect of different treatments on total cost, total return, net return $(\mathrm{LE} / \mathrm{fed})$ and net return $/ \mathrm{m}^{3}$.

\begin{tabular}{|c|c|c|c|c|c|c|c|c|c|c|}
\hline \multirow[b]{2}{*}{ 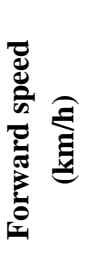 } & \multirow[b]{2}{*}{ 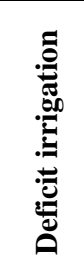 } & \multirow[b]{2}{*}{ 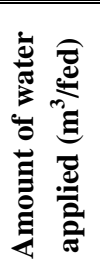 } & \multicolumn{4}{|c|}{ Broadcasting } & \multicolumn{4}{|c|}{ Fertigation } \\
\hline & & & 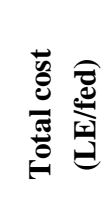 & 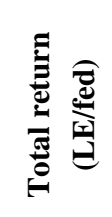 & 总 & 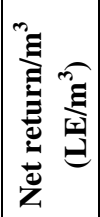 & 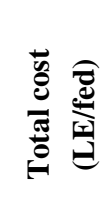 & & 总 & 葛 \\
\hline \multirow{3}{*}{2.1} & Zero & 1989 & 2714.0 & 6057.8 & 3343.8 & 1.68 & 2664.0 & 6708.6 & 4044.6 & 2.03 \\
\hline & $15 \%$ & 1750 & 2564.0 & 5876.0 & 3312.0 & 1.89 & 2514.0 & 6517.2 & 4003.2 & 2.29 \\
\hline & $30 \%$ & 1527 & 2414.0 & 5148.7 & 2734.7 & 1.79 & 2364.0 & 5837.7 & 3473.7 & 2.27 \\
\hline \multirow{3}{*}{3.6} & Zero & 1989 & 2683.0 & 6383.2 & 3700.2 & 1.86 & 2633.0 & 7225.4 & 4592.4 & 2.31 \\
\hline & $15 \%$ & 1750 & 2533.0 & 6124.8 & 3591.8 & 2.05 & 2483.0 & 6938.3 & 4455.3 & 2.55 \\
\hline & $30 \%$ & 1527 & 2383.0 & 5493.2 & 3110.2 & 2.04 & 2333.0 & 6210.9 & 3877.9 & 2.54 \\
\hline \multirow{3}{*}{4.5} & Zero & 1989 & 2685.0 & 5876.1 & 3191.1 & 1.60 & 2635.0 & 6507.3 & 3872.3 & 1.95 \\
\hline & $15 \%$ & 1750 & 2535.0 & 5735.0 & 3200.0 & 1.83 & 2485.0 & 6360.8 & 3875.8 & 2.21 \\
\hline & $30 \%$ & 1527 & 2385.0 & 5030.2 & 2645.2 & 1.73 & 2335.0 & 5703.4 & 3368.4 & 2.21 \\
\hline \multirow{3}{*}{6.3} & Zero & 1989 & 2688.0 & 5821.5 & 3133.5 & 1.58 & 2638.0 & 6589.5 & 3951.5 & 1.99 \\
\hline & $15 \%$ & 1750 & 2538.0 & 5580.1 & 3042.1 & 1.74 & 2488.0 & 6189.0 & 3701.0 & 2.11 \\
\hline & $30 \%$ & 1527 & 2388.0 & 4914.5 & 2526.5 & 1.65 & 2338.0 & 5572.3 & 3234.3 & 2.12 \\
\hline
\end{tabular}

Source: calculated from table (9). 
The maximum net return $/ \mathrm{m}^{3}$ was $2.55 \mathrm{LE} / \mathrm{m}^{3}$ under $15 \%$ deficit irrigation, forward speed $3.6 \mathrm{~km} / \mathrm{h}$ and fertigation method, while the minimum value was $1.65 \mathrm{LE} / \mathrm{kg}$ under $30 \%$ deficit irrigation, forward speed $6.3 \mathrm{~km} / \mathrm{h}$ and broadcasting method.

The data indicated that the maximum values of total return and net return were 7225.4 and 4592.4 L.E/fed, respectively, under fertigation method, $3.6 \mathrm{~km} / \mathrm{h}$ forward speed and zero deficit irrigation.

By using 15\% deficit irrigation had higher value of net return $/ \mathrm{m}^{3}$ (2.55 $\mathrm{LE} / \mathrm{m}^{3}$ ) and the net return decreased by $3 \%$ compared with zero deficit irrigation, vice versa was saved water about $12 \%$ and increased the cultivated area about $12 \%$ under the optimum condition through this studies using $3.6 \mathrm{~km} / \mathrm{h}$ forward speed and fertigation method.

\section{CONCLUSION}

\section{Results could be summarized as follows:}

- There are an effect of different forward speed on the field capacity, scattering and field efficiency.

- Highest amount of water applied $\left(1989 \mathrm{~m}^{3} / \mathrm{fed}\right)$ was obtained under zero deficit irrigation compared with 30\% deficit irrigation (1527 $\mathrm{m}^{3} /$ fed), by about $23 \%$ enhancement.

- There are significant effect of different treatments at 5\% on seed and straw productivity, the highest seed and straw productivity (755 and $1310 \mathrm{~kg} / \mathrm{fed}$ ) was obtained under zero deficit irrigation, forward speed $3.6 \mathrm{~km} / \mathrm{h}$ and fertigation method compared with $30 \%$ deficit irrigation, forward speed $6.3 \mathrm{~km} / \mathrm{h}$ and broadcasting method (513.54 and 804.32 $\mathrm{kg} / \mathrm{fed})$.

- There are significant effect at 5\% of different treatments on water and fertilizer use efficiency, fertigation method was higher than that under broadcasting method.

- Total cost of quinoa production under fertigation was lower than that when using broadcasting.

- Net return $/ \mathrm{m}^{3}$ under $15 \%$ deficit irrigation $\left(2.55 \mathrm{LE} / \mathrm{m}^{3}\right)$ was higher than under zero and $30 \%$ deficit irrigation $\left(2.31\right.$ and $2.54 \mathrm{LE} / \mathrm{m}^{3}$ ) under fertigation method and $3.6 \mathrm{~km} / \mathrm{h}$ forward speed. 


\section{REFERENCES}

Abdel-Aziz, A. A. and K. F. El-Bagoury (2008). Fertigation for improving pea productivity in new reclaimed lands. The $15^{\text {th }}$ Annual Conference of the Misr Society of Ag. pp. 459-476.

Abou El-Azem, A. M. (2009). Optimum water use for grain sorghum based on evaporation pan coefficients. Water science, (45): 19-42.

Ahmad, S. H., R. Ahmad, M. Y. Ashraf and E. A. Waraich (2009). Sunflower (Helianthus annuus L.) response to drought stress at germination and seedling growth stages. Pak. J. Bot. 41(2): 647654.

APHA, American Public Health association (1989). Standard methods for examination water and wastewater Washington DC, $17^{\text {th }}$ ed.

Arnaout, M. I. (1999). Comparative study between fertigation and conventional methods of fertilizer application through different irrigation systems. Misr. J. Ag. Eng., 16 (2): 209-217.

El-Gindy, A. M. (1988). Modern chemigation techniques for vegetable crops under Egyptian conditions. Misr J. of Agric. Eng., 5(1): 99111.

Embaby, A. T. (1985). A comparison of different mechanization system for cereal production. M.Sc. Thesis, Agric.Eng., Cairo Univ.

Erdem, T.; Y. Erdem, A. H. Orta and H. Okursoy (2006). Use of a crop water stress index for scheduling the irrigation of sunflower (Helianthus annuus L.). Turk. J. Agric. For. 30: 11-20.

FAO (2012). FAOStat data. http://faostat.fao.org.

Fghire R., O. I. Ali, O. Benlhabib and S. Wahbi (2015) Deficit irrigation and fertilization impact on quinoa water and yield productions. Conference: sustainable water use for securing food production in the Mediterranean region under changing climate, at Agadir, Morocco.

Israelsen, O. W. and V. E. Hansen (1962). Irrigation principles and practices. $3^{\text {th }}$ Edit. John Willey and Sons. Inc., New York.

Kepner, R. A.; R. Bainer and E. Barger (1978). Principles of farm machinery. Third Edition, AVI. Publishing company, INC. Westport, Connecticut, U.S.A.

Ogungbenle, H. N. (2003). Nutritional evaluation and functional properties of quinoa (Chenopodium quinoa Willd.) flour. International Journal of Food Sciences and Nutrition 54, 153 -158. 
Pene, C.B.G., and G.K. Edi (1996). Sugarcane yield response to deficit irrigation at two growth stages. In: Nuclear Techniques to Assess Irrigation Schedules for Field Crops. IAEA, TECDOC 888, pp. 115-129, Vienna.

Peterson, R. G. and L. D. Calvin (1965). Sampling JNCA Blac (ed) methods of soil analysis. S. Am. Soc. Agron. 9 Modison W1. Agron. 9: $54-71$.

Shams, A.S. (2010). Combat degradation in rainfed areas by introducing new drought tolerant crops in Egypt. $4^{\text {th }}$ international Conference on Water Resources and Arid Environments, Riyadh, Saudi Arabia, 5- 8 December, 575-582.

Shams, A.S. (2012). Response of quinoa to nitrogen fertilizer rates under sandy soil conditions. Proc. $13^{\text {th }}$ international Conf. Agron., Fac.of Agic., Benha Univ., Egypt, 9-10 September , 95 - 205.

Snedecor, G. W. and W. G. Cochran (1967). Statistical Methods 6th. Ed., Ames: The Iowa State University U.S.A., Press, 593p.

Table (9): Total cost under different treatments.

\begin{tabular}{|c|c|c|c|c|c|c|c|c|}
\hline $\begin{array}{l}\text { Fertilizer } \\
\text { methods }\end{array}$ & $\begin{array}{c}\text { Forward } \\
\text { speed } \\
(\mathbf{k m} / \mathbf{h}) \\
\end{array}$ & $\begin{array}{c}\text { Deficit } \\
\text { irrigation }\end{array}$ & $\begin{array}{c}\text { Soil } \\
\text { preparation }\end{array}$ & $\begin{array}{l}\text { Chemical } \\
\text { fertilizer }\end{array}$ & Labor & $\begin{array}{c}\text { Irrigation } \\
\text { (fixed + } \\
\text { running) }\end{array}$ & $\begin{array}{c}\text { Weed } \\
\text { and best } \\
\text { control }\end{array}$ & $\begin{array}{l}\text { Total } \\
\text { cost }\end{array}$ \\
\hline \multirow{12}{*}{ 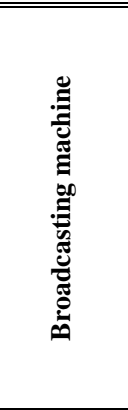 } & \multirow{3}{*}{2.1} & Zero & 214 & 350 & 800 & 1100 & 250 & 2714 \\
\hline & & $15 \%$ & 214 & 350 & 800 & 950 & 250 & 2564 \\
\hline & & $30 \%$ & 214 & 350 & 800 & 800 & 250 & 2414 \\
\hline & \multirow{3}{*}{3.6} & Zero & 183 & 350 & 800 & 1100 & 250 & 2683 \\
\hline & & $15 \%$ & 183 & 350 & 800 & 950 & 250 & 2533 \\
\hline & & $30 \%$ & 183 & 350 & 800 & 800 & 250 & 2383 \\
\hline & \multirow{3}{*}{4.5} & Zero & 185 & 350 & 800 & 1100 & 250 & 2685 \\
\hline & & $15 \%$ & 185 & 350 & 800 & 950 & 250 & 2535 \\
\hline & & $30 \%$ & 185 & 350 & 800 & 800 & 250 & 2385 \\
\hline & \multirow{3}{*}{6.3} & Zero & 188 & 350 & 800 & 1100 & 250 & 2688 \\
\hline & & $15 \%$ & 188 & 350 & 800 & 950 & 250 & 2538 \\
\hline & & $30 \%$ & 188 & 350 & 800 & 800 & 250 & 2388 \\
\hline \multirow{12}{*}{ : } & \multirow{3}{*}{2.1} & Zero & 214 & 350 & 750 & 1100 & 250 & 2664 \\
\hline & & $15 \%$ & 214 & 350 & 750 & 950 & 250 & 2514 \\
\hline & & $30 \%$ & 214 & 350 & 750 & 800 & 250 & 2364 \\
\hline & \multirow{3}{*}{3.6} & Zero & 183 & 350 & 750 & 1100 & 250 & 2633 \\
\hline & & $15 \%$ & 183 & 350 & 750 & 950 & 250 & 2483 \\
\hline & & $30 \%$ & 183 & 350 & 750 & 800 & 250 & 2333 \\
\hline & \multirow{3}{*}{4.5} & Zero & 185 & 350 & 750 & 1100 & 250 & 2635 \\
\hline & & $15 \%$ & 185 & 350 & 750 & 950 & 250 & 2485 \\
\hline & & $30 \%$ & 185 & 350 & 750 & 800 & 250 & 2335 \\
\hline & \multirow{3}{*}{6.3} & Zero & 188 & 350 & 750 & 1100 & 250 & 2638 \\
\hline & & $15 \%$ & 188 & 350 & 750 & 950 & 250 & 2488 \\
\hline & & $30 \%$ & 188 & 350 & 750 & 800 & 250 & 2338 \\
\hline
\end{tabular}

Source: Calculated under different treatments. 


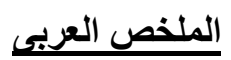 \\ دراسة تأثير بعض العوامل على محصول الكينوا}

د/ محمد عنتر محمد مرسى' د/ كمال ابراهيم وصفى أحمد' د دمحمد حلمى راضى'

تعتبر الكينو ا من المحاصبل التى يتم التغذيه عليها سو اء كحبوب او خضروات ، حيث تحتوى

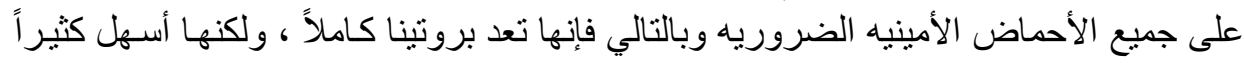

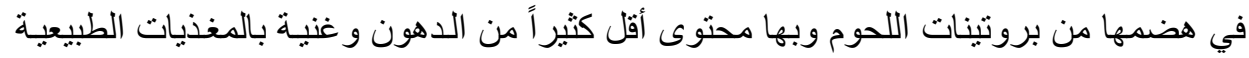

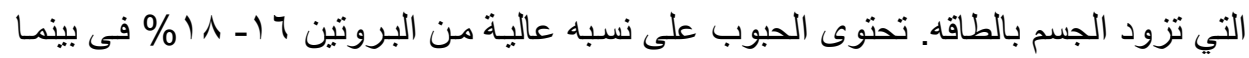

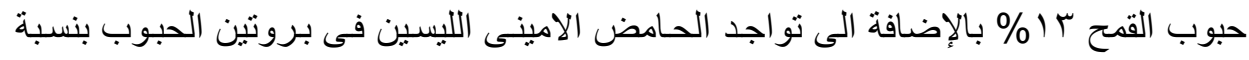

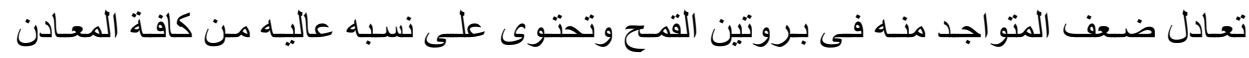

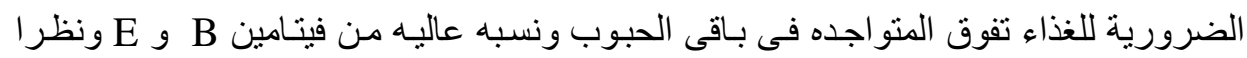

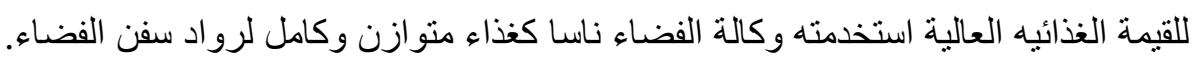

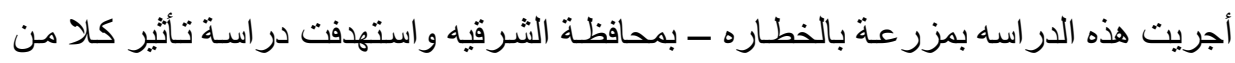

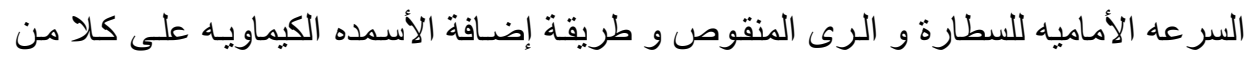

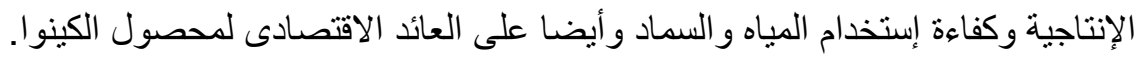
ومن أهم النتائج التى توصلت اليهاعة الدراسة:

ا ـ بزيادة سر عة لسطارة زادت السعه الحقليه و زيادة التشتت، بينما قلت الكفاءة الحقليه.

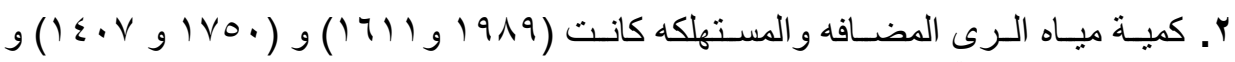

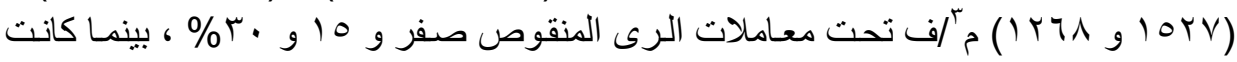

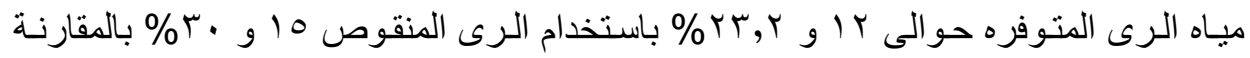

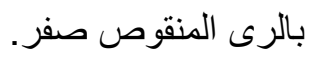
ب. وجد تاثثير معنوى للمعـاملات المختلفة و أعلى انتاجية بذور وقش وكفاءة استخدام الميـاه

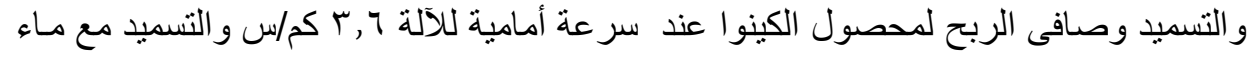
الرى.

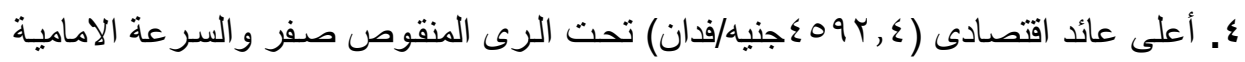

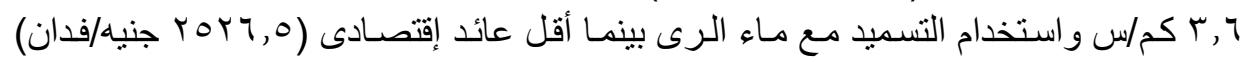

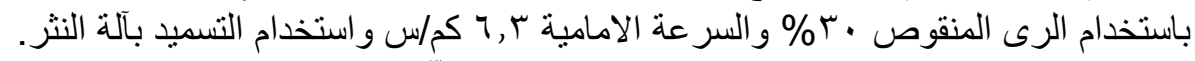

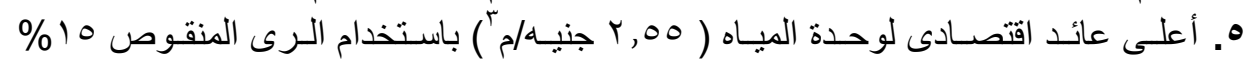

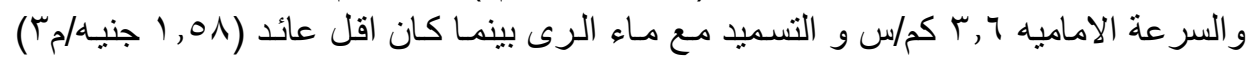

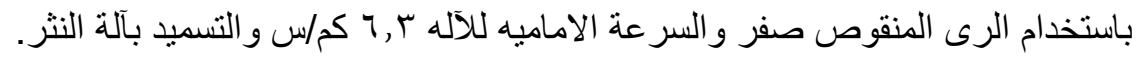

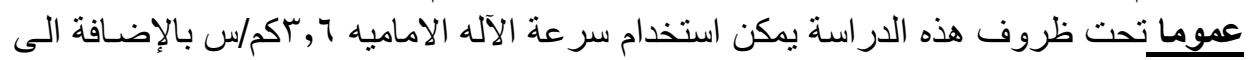

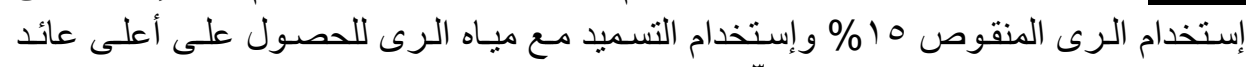

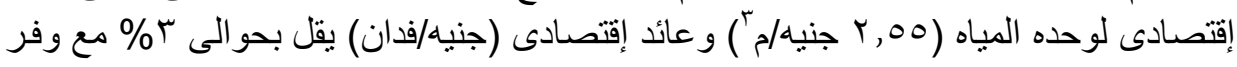
فى مياه الرى تعادل Y I \% وبالتالى زيادة الانتاجية لنفس كمية المياه المضافهـ

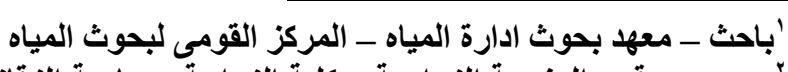

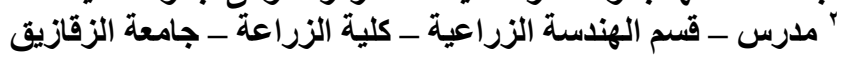

